\title{
Native glycine receptor subtypes and their physiological roles
}

Joseph W. Lynch

Queensland Brain Institute and School of Biomedical Sciences, University of Queensland, Brisbane, QLD 4072, Australia.

Corresponding author: Dr. Joseph Lynch,

Queensland Brain Institute, University of Queensland, Brisbane, QLD 4072, Australia.

Phone: $\quad+61733466375$

Fax: $\quad+61733466301$

Email: $\quad$ j.lynch@uq.edu.au

Running title: Native glycine receptor subtypes 


\section{Abstract}

The glycine receptor chloride channel (GlyR), a member of the pentameric Cys-loop ion channel receptor family, mediates inhibitory neurotransmission in the spinal cord, brainstem and retina. They are also found pre-synaptically, where they modulate neurotransmitter release. Functional GlyRs are formed from a total of five subunits $(\alpha 1-\alpha 4, \beta)$. Although $\alpha$ subunits efficiently form homomeric GlyRs in recombinant expression systems, homomeric $\alpha 1, \alpha 3$ and $\alpha 4$ GlyRs are weakly expressed in adult neurons. In contrast, $\alpha 2$ homomeric GlyRs are abundantly expressed in embryonic neurons, although their numbers decline sharply by adulthood. Numerous lines of biochemical, biophysical, pharmacological and genetic evidence suggest the majority of glycinergic neurotransmission in adults is mediated by heteromeric $\alpha 1 \beta$ GlyRs. Immunocytochemical co-localisation experiments suggest the presence of $\alpha 2 \beta, \alpha 3 \beta$ and $\alpha 4 \beta$ GlyRs at synapses in the adult mouse retina. Immunocytochemical and electrophysiological evidence also implicates $\alpha 3 \beta$ GlyRs as important mediators of glycinergic inhibitory neurotransmission in nociceptive sensory neuronal circuits in peripheral laminae of the spinal cord dorsal horn. It is yet to be determined why multiple GlyR synaptic subtypes are differentially distributed in these and possibly other locations. The development of pharmacological agents that can discriminate strongly between different $\beta$ subunitcontaining GlyR isoforms will help to address this issue, and thereby provide important insights into a variety of central nervous system functions including retinal signal processing and spinal pain mechanisms. Finally, agents that selectively potentiate different GlyR isoforms may be useful as therapeutic lead compounds for peripheral inflammatory pain and movement disorders such as spasticity.

Keywords: chloride channel, inhibitory synaptic transmission, ligand-gated ion channel, Cys-loop receptor 


\section{Introduction}

The glycine receptor $\mathrm{Cl}^{-}$channel (GlyR) is classically known for mediating inhibitory synaptic transmission between interneurons and motor neurons in reflex circuits of the spinal cord. Glycine was originally proposed as an inhibitory neurotransmitter based on an analysis of its distribution in

the spinal cord (Aprison and Werman, 1965; Davidoff et al., 1967). Subsequent experiments showed that it activated a strychnine-sensitive inhibitory $\mathrm{Cl}^{-}$conductance in spinal cord neurons (Curtis et al., 1967; Werman et al., 1967). Purification of the GlyR from rat spinal cord by strychnine affinity chromatography revealed three distinct polypeptides of molecular mass 48, 58 and $98 \mathrm{kDa}$ (Pfeiffer et al., 1982). The 48 and $58 \mathrm{kDa}$ peptides were later shown to correspond to the $\alpha 1$ and $\beta$ subunits, respectively.

Cloning of the $\alpha 1$ GlyR subunit was reported in 1987 (Grenningloh et al., 1987) and its homology with the previously cloned nicotinic acetylcholine receptor (nAChR) led to its inclusion in the Cysloop family of ligand-gated ion channel receptors. The $\beta$ subunit, cloned by the Betz group in 1990 (Grenningloh et al., 1990), was found to share a 47\% amino acid sequence homology with the $\alpha 1$ subunit. The $98 \mathrm{kDa}$ peptide was later identified as the cytoplasmic protein, gephyrin, which is essential for clustering GlyRs at postsynaptic densities via direct interactions between the GlyR $\beta$ subunit and intracellular microtubules (Fritschy et al., 2008). The $\alpha 2, \alpha 3$ and $\alpha 4$ subunits and several splice variants were subsequently cloned by homology screening (Lynch, 2004). The $\alpha$ subunits share a $>90 \%$ amino acid sequence homology with each other. The anatomical distributions, developmental regulation, physiological roles and pharmacological properties of all known GlyR isoforms will be considered below.

Functional Cys-loop receptors comprise homomeric or heteromeric pentameric oligomers with each of the five subunits arranged symmetrically in a ring around a central ion-conducting pore. The GlyR structure is yet to be determined directly. However, by analogy with the known structures of 
other Cys-loop family members (Brejc et al., 2002; Miyazawa et al., 2003; Hilf and Dutzler, 2008), each GlyR subunit comprises a large extracellular amino-terminal domain that harbours the ligand binding sites and the eponymous Cys-loop. This connects to a bundle of four $\alpha$-helical transmembrane domains (labelled M1 - M4) with a large intracellular domain between M3 and M4 and a short extracellular C-terminal tail. Each of the five subunits contributes an amphipathic M2 domain to the lining of the central water-filled pore. Structural analyses of other Cys-loop receptors suggest that the channel gate is located centrally in the M2 domain (Miyazawa et al., 2003; Hilf and Dutzler, 2008).

The ligand-binding domain is mainly comprised of $\beta$-sheets, connected by flexible loops. The agonist binding site is a pocket-like structure at the subunit interface, accessible from the outside of the structure (Brejc et al., 2002). It is formed by six domains: three loops from one subunit form the principle binding site (domains A-C) and three $\beta$-sheets from the adjacent subunit form the complementary binding site (domains D-F). As with other Cys-loop receptors, agonist binding to a single site simultaneously converts all subunits to the activated state (Corringer et al., 2000). Three bound glycine molecules are sufficient to maximally activate $\alpha$ homomeric GlyRs (Lewis et al., 2003; Beato et al., 2004).

Autoradiographic analysis of $\left[{ }^{3} \mathrm{H}\right]$ strychnine binding sites identified high levels of surface-expressed GlyRs in the following regions of the rat central nervous system: spinal cord, trigeminal nuclei, superior olive nucleus, nuclei of lateral lemniscus, vestibular nuclei, cuneate nucleus, gracile nucleus, hypoglossal nucleus, dorsal motor nucleus of vagus and superior colliculus (Zarbin et al., 1981). Immunocytochemistry using a generic $\alpha$ subunit monoclonal antibody also showed high levels of GlyR expression in the spinal cord and in numerous brainstem nuclei, but also in the retina, olfactory bulb, hippocampus and cerebellum (Araki et al., 1988; van den Pol and Gorcs, 1988).

Electrophysiological studies have identified glycinergic synapses in many of these regions (Legendre, 2001; Lynch, 2004). As these techniques do not discriminate among GlyR subtypes, they 
reveal the net distribution of functional GlyRs. Our understanding of the distributions of individual subunits will be considered below.

\section{Recombinant receptors}

\section{Expression, pentameric formation and subunit stoichiometries}

All $\alpha$ subunits express robustly as functional homomers in both Xenopus oocyte and HEK293 mammalian cell expression systems. Biochemical evidence for the formation of homomeric pentamers following injection of $\alpha 1$ subunit cRNA into Xenopus oocytes is presented in (Griffon et al., 1999). All $\alpha$ subunits probably co-assemble as heteromers with other $\alpha$ subunits. Evidence for functional $\alpha$ subunit heteromers comes from co-expression studies of a wild-type $\alpha 1$ subunit with a mutant (G167L) $\alpha 2$ subunit with strongly impaired glycine sensitivity (Kuhse et al., 1993). Coexpression of cRNAs in differing ratios yielded currents that exhibited a monophasic glycine doseresponse relationship with a low Hill coefficient suggesting a mixture of subunits. The control experiment involved injecting $\alpha 1$ and $\alpha 2$ subunit mRNA two days apart. This resulted in a superposition of two widely separated dose-responses, indicating the existence of distinct $\alpha 1$ and mutant $\alpha 2$ homomeric GlyRs. It is not known whether different $\alpha$ subunits recombine in a particular stoichiometry or (as is suspected) in a random binomial manner.

Electrophysiological studies have established that the expression of $\beta$ subunits alone produces no glycine-gated currents (Bormann et al., 1993) and biochemical evidence indicates that $\beta$ subunits do not assemble as pentameric homomers (Griffon et al., 1999). However, there is a variety of evidence that $\beta$ subunits form heteromers with $\alpha$ subunits in recombinant expression systems. First, biochemical cross-linking experiments with GlyRs purified from rat spinal cord provided evidence for the pentameric co-assembly of $\alpha 1$ and $\beta$ subunits (Langosch et al., 1988). Co- 
immunoprecipitation of $\alpha 1$ subunits using a $\beta$ subunit-specific antibody from cells transfected with $\alpha 1$ and $\beta$ subunits provided biochemical evidence for a direct interaction (Pribilla et al., 1992; Oertel et al., 2007). There is also pharmacological evidence for the formation of $\alpha \beta$ heteromers. The original assay, and still the standard means of pharmacologically identifying heteromeric GlyRs, is picrotoxin sensitivity. Homomeric $\alpha$ GlyRs are potently inhibited by picrotoxin whereas glycinegated currents in cells transfected with $\alpha$ and $\beta$ cDNA exhibit a dramatically reduced picrotoxin sensitivity (Pribilla et al., 1992). Other pharmacological tools for differentiating homomeric from heteromeric GlyRs are considered below. Finally, co-assembly of $\alpha$ and $\beta$ subunits results in a significantly reduced single channel conductance (Table 1) and differences in single channel kinetic behaviour (Beato et al., 2004; Burzomato et al., 2004).

The subunit stoichiometry of $\alpha 1 \beta$ GlyRs has recently been investigated by Gruzdinska and colleagues (Grudzinska et al., 2005). On the basis of the severity of mutations to corresponding glycine binding sites in $\alpha 1$ and $\beta$ subunits, these authors reasoned that $\beta$ subunits predominated in $\alpha 1 \beta$ GlyRs. This hypothesis was confirmed by demonstrating that an $\alpha 1-\beta$ concatemer produced functional heteromers when co-expressed with $\beta$ homomers but not when expressed alone or with $\alpha 1$ subunits (Grudzinska et al., 2005). However, this result is consistent with either a $2 \alpha: 3 \beta$ or a $1 \alpha: 4 \beta$ stoichiometry. Quantitation of radio-labelled methionine levels in affinity purified recombinant $\alpha 1$ and $\alpha 1 \beta$ GlyRs was consistent with a $2 \alpha: 3 \beta$ stoichiometry. Together, these results imply a subunit arrangement of $\beta-\alpha-\beta-\alpha-\beta$. However, since previous more indirect approaches all suggested a 3 $\alpha: 2 \beta$ stoichiometry (Becker et al., 1988; Kuhse et al., 1993; Burzomato et al., 2003), confirmation of the putative $2 \alpha: 3 \beta$ stoichiometry by other techniques is warranted.

\section{Biophysical and pharmacological properties}


GlyRs display several single channel conductance states. A comparison of these states in recombinant GlyRs is provided in Table 1. In general, homomeric GlyRs exhibit five states with the open probabilities favouring the highest conducting states. Co-expression of $\alpha$ subunits with $\beta$ subunits eliminates the highest conductance levels leaving a $45 \mathrm{pS}$ state as the most frequently visited level. As cell-attached recordings do not generally report the lowest conducting levels (e.g., compare (Burzomato et al., 2004) with (Bormann et al., 1993)), it seems that the probability of receptors entering sub-conductance states is increased by membrane patch excision. There is no evidence to date for subunit-specific GlyR agonists. All homomeric and heteromeric GlyR subtypes exhibit broadly similar sensitivities to glycine (Pribilla et al., 1992; Yang et al., 2007). The rank order potency of amino acid agonists at $\alpha 1$ homomeric and $\alpha 1 \beta$ heteromeric GlyRs is glycine $>\beta$-alanine $>$ taurine (Barker and Ransom, 1978; Schmieden et al., 1989; Lynch et al., 1997). Although this potency sequence has not been systematically verified in all GlyR isoforms, it seems unlikely that the amino acid agonist potency sequence will be useful for defining particular GlyR subtypes. The only non-amino acid agonist identified so far, ivermectin, has a similar sensitivity at $\alpha 1$ and $\alpha 1 \beta$ GlyRs (Shan et al., 2001) and it also potently activates $\alpha 2$ and $\alpha 3$ homomeric GlyRs (T. Lynagh and J. Lynch, unpublished data). However, one notable difference among GlyR $\alpha$ subunit types is activation rate: the recombinant homomeric $\alpha 2$ GlyR has been shown to activate at a much lower rate than $\alpha 1 \beta$ GlyRs (Mangin et al., 2003). The macroscopic or single channel kinetic properties of all GlyR isoforms have not yet been investigated in detail. The molecular pharmacological properties of recombinant GlyR subtypes have recently been reviewed (Webb and Lynch, 2007). Table 2 presents a summary of only those pharmacological agents known to differ in potency or mode of action from one GlyR subtype to the next. Although many compounds exhibit modest subunit-specific differences, to date there are few substances with sufficient discriminatory capacity to identify the presence of $\alpha 1, \alpha 2$ and $\alpha 3$ subunits in either homomeric or heteromeric GlyRs. However, several probes (e.g., picrotoxin) are available that can 
distinguish strongly between $\alpha$ homomeric and $\alpha \beta$ heteromeric GlyRs. Unfortunately, most of these agents also have potent effects on other receptor types, which limits their utility as probes for establishing the physiological role of different GlyR subtypes. There is thus abundant scope for the development of novel GlyR subunit-specific pharmacological probes.

\section{Native receptors}

\section{Homomeric $\alpha 2$ GlyRs}

Analysis of mRNA and protein expression levels revealed that GlyRs in the fetal rat are predominantly $\alpha 2$ homomers (Becker et al., 1988; Malosio et al., 1991b; Watanabe and Akagi, 1995). However, $\alpha 2$ expression declines sharply between birth and postnatal week three, while expression of $\alpha 1$ and $\beta$ subunits increases over the same period. Thus, in the rat, a developmental switch from $\alpha 2$ homomeric GlyRs to $\alpha 1 \beta$ heteromeric GlyRs takes place between birth and the third postnatal week. As $\alpha 2$ is the most abundantly expressed $\alpha$ subunit in prenatal rats, it would therefore be reasonable to assume that large conductance $(100 \mathrm{pS})$ glycine-activated channels on embryonic neuronal membranes would provide evidence for the expression of homomeric $\alpha 2$ GlyRs. Indeed, such evidence has been provided by several laboratories ( Singer et al., 1998; Mangin et al., 2002; Takahashi et al., 1992). The existence of $\alpha 2$ homomers in immature central neurons is also implied by the relatively high picrotoxin sensitivity of glycine-gated currents recorded from these neurons (Kungel and Friauf, 1997; Mangin et al., 2002; Wang et al., 2005). Given that $\alpha 2$ mRNA and protein are strongly expressed in embryonic neurons, and the fact that intracellular chloride concentrations are high in these neurons (Rivera et al., 1999), it is probable that homomeric $\alpha 2$ GlyRs mediate the depolarising glycine-gated chloride flux that stimulates the calcium influx (Flint et al., 1998) necessary for the development of numerous neuronal specialisations, including glycinergic synapses (Kneussel and Betz, 2000). Surprisingly, however, knockout of the $\alpha 2$ subunit 
had no obvious effect on neuronal development, although it does reduce rod photoreceptor numbers and eliminate a tonic glycine-gated chloride conductance in embryonic cortical neurons (Table 3).

\section{Homomeric $\alpha 1$ and $\alpha 3$ GlyRs}

Non-synaptic GlyRs are widely distributed throughout the adult nervous system. If homomeric $\alpha 1$ or $\alpha 3$ GlyRs exist in vivo then they are most likely to be extrasynaptic (as they cannot bind gephyrin) Thus, they should be identifiable as large (80-100 pS) unitary currents in single channel recordings from neuronal membrane patches, or as picrotoxin-sensitive whole-cell glycine currents. However, single channels gated by glycine in the somatic membranes of juvenile or adult spinal or brainstem neurons generally exhibit maximal unitary conductances near 40 pS (Takahashi et al., 1992; Singer et al., 1998; Ali et al., 2000; Beato and Sivilotti, 2007) consistent with an $\alpha \beta$ stoichiometry (Table 1). Larger (80-100 pS) conductance channels consistent with homomeric $\alpha 1$ or $\alpha 3$ GlyRs, have seldom been observed, strongly suggesting that homomeric $\alpha 1$ or $\alpha 3$ GlyRs are not expressed to any significant degree in the somatic regions of adult neurons. There also does not seem to be a strong case for the existence of picrotoxin-sensitive glycine-gated currents in somatic electrophysiological recordings from adult neurons.

There is, however, sporadic evidence that homomeric GlyRs may be present in non-somatic locations on central neurons. In particular, several studies have indicated that GlyRs are present on presynaptic nerve terminals of central neurons where they may be involved in controlling the release of glutamate (Turecek and Trussell, 2001, 2002), glycine (Jeong et al., 2003) or GABA (Ye et al., 2004). Single channel recordings from a limited number of presynaptic nerve terminals of adult auditory brainstem neurons revealed the presence of glycine-gated channels with an unitary conductance of $92 \mathrm{pS}$ (Turecek and Trussell, 2002), suggesting that at least some presynaptic GlyRs may be homomeric. Another study, performed on neurons of the rat supraoptic nucleus, presented both immunohistochemical and pharmacological evidence for a differential distribution of 
heteromeric GlyRs and homomeric GlyRs. The former were distributed exclusively on the soma and dendrites whereas the later were found exclusively on distal axonal regions (Deleuze et al., 2005). However, further studies are required to substantiate the case for the segregated distribution of homomeric and heteromeric GlyRs at these or other locations in adult neurons.

\section{Heteromeric $\alpha 1 \beta$ GlyRs}

In-situ hybridisation in the adult rat reveals $\beta$ subunit mRNA to be widely distributed throughout the spinal cord, retina and brain and $\alpha 1$ mRNA to be restricted primarily to the spinal cord, a subset of retinal neurons and a host of brainstem nuclei (Malosio et al., 1991b; Sato et al., 1991; Greferath et al., 1994). It is thus feasible that heteromeric $\alpha 1 \beta$ GlyRs may exist in all central nervous system areas where $\alpha 1$ GlyRs are expressed. Indeed, as noted above, subunit-crosslinking and coimmunoprecipitation experiments of GlyR protein purified from rat spinal cord demonstrated a physical interaction between $\alpha 1$ and $\beta$ subunits in vivo (Langosch et al., 1988; Pribilla et al., 1992; Oertel et al., 2007). As gephyrin is essential for GlyR clustering at synapses (Fritschy et al., 2008), and it does so only by binding only to GlyR $\beta$ subunits (Meyer et al., 1995; Bedet et al., 2006; Kim et al., 2006), synaptic GlyRs must by inference be $\alpha \beta$ heteromers. Furthermore, because $\alpha 1$ is the most abundantly expressed of all $\alpha$ subunits in adult rat (Becker et al., 1988; Malosio et al., 1991b), it is generally assumed that most glycinergic synapses in the adult rat are mediated by $\alpha 1 \beta$ GlyRs. In support of this, the decay kinetics of spontaneous glycinergic inhibitory postsynaptic currents (IPSCs) in rat spinal motor neurons is well accounted for by activation mechanisms that describe single-channel behaviour of $\alpha 1 \beta$ heteromers rather than $\alpha 1$ homomers (Burzomato et al., 2004). Furthermore, as discussed above, single channel conductance evidence favours a preponderance of heteromeric rather than homomeric GlyRs on neuronal membrane surfaces. However, there is as yet very little direct immunocytochemical or pharmacological evidence that most synaptic currents are mediated by $\alpha 1 \beta$ to the exclusion of other GlyR isoforms. 
Given that $\alpha 1 \beta$ GlyRs most likely mediate the bulk of glycinergic inhibitory transmission in adult spinal cord brainstem and retina, it is reasonable to hypothesise that knockdown or knockout of

either gene would have severe and similar neurological consequences. As summarised in Table 3, this is indeed the case. The effect of reducing the expression of either subunit is to produce a hyperekplexia phenotype, characterised by an exaggerated reflex startle response to unexpected stimuli, which is often accompanied by temporary but complete muscular rigidity. This indicates an impairment of inhibitory neurotransmission in reflex circuits of the spinal cord where synaptic GlyRs are well known to exist. Thus, genetic data provide a compelling case for the widespread synaptic distribution of $\alpha 1 \beta$ GlyRs.

\section{Heteromeric $\alpha 2 \beta$ GlyRs}

As $\alpha 2$ subunit mRNA and protein expression levels undergo a sharp postnatal decline (Becker et al., 1988; Malosio et al., 1991b; Watanabe and Akagi, 1995), synapses containing $\alpha 2 \beta$ GlyRs are likely to be sparse in the adult. However, a substantial proportion of glycinergic synapses in the inner plexiform layer of the adult mouse retina show co-localisation of immunoreactivity for $\alpha 2$ subunits and gephyrin (Haverkamp et al., 2004), suggesting $\alpha 2$ subunits are synaptically localised. Indeed, functional evidence has recently been presented for $\alpha 2 \beta$-mediated synapses on wide-field amacrine cells in the adult rat retina (Veruki et al., 2007). There is also evidence that $\alpha 2$-containing synaptic GlyRs predominate transiently in central neurons around the time of birth in the rat (Takahashi et al., 1992; Singer et al., 1998; Ali et al., 2000); (Okabe et al., 2004), during the developmental switch from $\alpha 2$ homomeric to $\alpha 1 \beta$ heteromeric GlyRs. However, the lack of obvious neurological and visual deficits on $\alpha 2$ knockout mice suggests that the properties of $\alpha 2$-containing GlyRs are not indispensable for normal central nervous system function (Table 3).

\section{Heteromeric $\alpha 3 \beta$ GlyRs}


Although expression of the GlyR $\alpha 3$ subunit increases with age, it is weakly expressed at all developmental stages relative to the $\alpha 1$ subunit (Malosio et al., 1991a). One report presented functional and immunohistochemical evidence for their expression in several central nervous system regions including the hippocampus (Meier et al., 2005), although their abundance relative to $\alpha 1$ GlyRs was not quantitated. The distribution of the $\alpha 3$ subunit has been mapped in most detail in the retina (Haverkamp et al., 2003) and in nociceptive neurons in the laminae I and II of the spinal cord dorsal horn (Harvey et al., 2004). Light microscopy suggested that $\alpha 3$ subunit-specific immunofluorescence was present in around half the glycinergic synaptic puncta in the inner plexiform layer of the retina, where they were associated primarily with neurons of the cone pathways (Haverkamp et al., 2003; Haverkamp et al., 2004). Immunocytochemical evidence was also presented for the co-localisation of $\alpha 3$ subunits and gephyrin at individual synaptic puncta in laminae I and II of the mouse spinal cord dorsal horn (Harvey et al., 2004). It had earlier been shown that glycinergic IPSCs on these neurons were inhibited by the inflammatory mediator, prostaglandin type $\mathrm{E}_{2}\left(\mathrm{PGE}_{2}\right)$, via $\mathrm{EP}_{2}$ receptor-mediated activation of PKA-dependent phosphorylation (Ahmadi et al., 2002). Consistent with this, recombinant $\alpha 3$ GlyRs were inhibited by $\mathrm{PGE}_{2}$ via PKAdependent phosphorylation whereas $\alpha 1$ GlyRs (which do not have PKA phosphorylation sites) were not (Harvey et al., 2004). A GlyR $\alpha 3$ knockout mouse was generated to test whether the $\alpha 3$ subunit was the in vivo target of the inflammatory stimuli. The $\mathrm{PGE}_{2}$-dependent decrease of lamina II glycinergic IPSCs was duly found to be abolished in the GlyR $\alpha 3$-/- mice (Harvey et al., 2004). Behaviourally, normal and knockout mice responded similarly to non-painful tactile stimuli and acute inflammatory pain stimuli and no visual defects were reported. However, chronic peripheral inflammation produced pain sensitisation in normal animals but not in the knockouts (Table 3). Thus, these results show that $\alpha 3 \beta$ GlyRs do exist and are specifically inhibited during chronic inflammation. This result has established the GlyR as a potential therapeutic target for peripheral chronic inflammatory pain. 


\section{Homomeric $\alpha 4$ and heteromeric $\alpha 4 \beta$ GlyRs}

The GlyR $\alpha 4$ gene is a pseudo-gene in humans (Simon et al., 2004) and there is little evidence for its functional expression in rats (Piechotta et al., 2001). However, it is strongly expressed in the spinal cord, dorsal root ganglia, sympathetic ganglia and male genetic ridge of the chick (Harvey et al., 2000). Immunocytochemistry reveals a substantial co-localisation of $\alpha 4$ and gephyrin immunofluorescence in synaptic puncta of inner plexiform neurons of the mouse retina (Heinze et al., 2007).

\section{Conclusion}

Although all $\alpha$ subunits assemble efficiently into homomeric GlyRs in recombinant expression systems, there is scant evidence to date for the existence of homomeric $\alpha 1, \alpha 3$ and $\alpha 4$ GlyRs in adult vertebrates in vivo. However, it is likely that excitatory non-synaptic GlyRs in embryonic neurons are of the $\alpha 2$ subtype. A wide variety of evidence implicates heteromeric $\alpha 1 \beta$ GlyRs in mediating the majority glycinergic neurotransmission in adults. Immunocytochemical colocalisation experiments suggest the presence of $\alpha 2 \beta, \alpha 3 \beta$ and $\alpha 4 \beta$ GlyRs at synapses in the adult mouse retina. Immunocytochemical and electrophysiological evidence also implicates $\alpha 3 \beta$ GlyRs as important mediators of glycinergic inhibitory neurotransmission in nociceptive sensory neurons in peripheral laminae of the spinal cord dorsal horn. It is yet to be determined why multiple GlyR synaptic subtypes are present in these and possibly other locations. The development of pharmacological agents that can discriminate strongly between different $\beta$ subunit-containing GlyR isoforms will help to address this issue, and thereby provide important insights into retinal signal processing and spinal pain mechanisms. Unfortunately, however, currently available subunitspecific pharmacological probes are not sufficiently selective for discriminating among different $\beta$ 
subunit containing isoforms. Finally, experiments to date suggest that agents that selectively potentiate different GlyR isoforms may be useful as therapeutic lead compounds for peripheral inflammatory pain and movement disorders such as spasticity.

\section{Acknowledgements}

Research in the author's laboratory is supported by the National Health and Medical Research Council of Australia and the Australian Research Council. 
Table 1

\begin{tabular}{|c|c|c|c|c|c|c|c|}
\hline Singl & ann & Co & ance & f Rec & bina & GlyRs & \\
\hline & & & ductanc & states & pS) & & \\
\hline GlyR & I & II & III & IV & V & VI & References \\
\hline$\alpha 1$ & & $\begin{array}{l}75- \\
88^{*}\end{array}$ & $59-68$ & $43-49$ & $25-30$ & $15-18$ & $\begin{array}{c}\text { (Takahashi et al., } \\
\text { 1992; Bormann et al., } \\
\text { 1993; Rajendra et al., } \\
\text { 1995; Beato et al., } \\
\text { 2002) }\end{array}$ \\
\hline$\alpha 2$ & $111^{*}$ & $\begin{array}{l}88- \\
91^{*}\end{array}$ & $\begin{array}{l}66- \\
72^{*}\end{array}$ & $42-48$ & $24-36$ & & $\begin{array}{l}\text { (Takahashi et al., } \\
\text { 1992; Bormann et al., }\end{array}$ \\
\hline$\alpha 3$ & $105^{*}$ & 85 & 62 & 42 & 30 & 20 & (Bormann et al., 1993) \\
\hline$\alpha 1 \beta$ & & & & $\begin{array}{l}39- \\
44^{*}\end{array}$ & 29 & 20 & $\begin{array}{c}\text { (Bormann et al., 1993; } \\
\text { Burzomato et al., } \\
\text { 2004) }\end{array}$ \\
\hline$\alpha 2 \beta$ & 112 & 80 & & $54^{*}$ & 36 & & (Bormann et al., 1993) \\
\hline$\alpha 3 \beta$ & & & & $48^{*}$ & 34 & 23 & (Bormann et al., 1993) \\
\hline $\begin{array}{l}\text { * the } \\
\text { Note } \\
\text { condi } \\
\text { All st' } \\
150 \mathrm{n} \\
\text { expre } \\
\text { (Borm } \\
\text { (Raje } \\
\text { (Taka } \\
\text { (Beat } \\
\text { (Burz }\end{array}$ & $\begin{array}{l}\text { nce } \\
\text { S we } \\
\mathrm{Cl} \text { co } \\
\text { on sy } \\
n \text { et a } \\
\text { a et a } \\
\text { shi et } \\
\text { t al., } \\
\text { ato et }\end{array}$ & $\begin{array}{l}\text { tes } \\
\text { cond } \\
\text { entra } \\
\text { em, p } \\
1993 \\
1995 \\
., 199 \\
02):\end{array}$ & $\begin{array}{l}\text { rring c } \\
\text { ends th } \\
\text { d at ro } \\
\text { Othe } \\
\text { e poter } \\
\text { EK293 } \\
\text { EK } 293 \\
\text { Kenopl } \\
\text { 93 cel } \\
\text { HEK29 }\end{array}$ & $\begin{array}{l}\text { nductan } \\
\text { increas } \\
\text { m tempe } \\
\text { recordin } \\
\text { ial, patc } \\
\text { ells, }-70 \\
\text { cells; -5 } \\
\text { oocyte } \\
;-100 \text { n } \\
\text { cells; + }\end{array}$ & $\begin{array}{l}\text { e state } \\
\text { the pr } \\
\text { ature ( } \\
\text { condi } \\
\text {-clamp } \\
\mathrm{mV} \text {, ou } \\
\mathrm{mV} \text {, ol } \\
-80 \mathrm{~m} \\
\mathrm{~J} \text {, outs } \\
00 \mathrm{mV}\end{array}$ & $\begin{array}{l}\text { ability } \\
-24^{\circ} \\
\text { ns wer } \\
\text { nfigura } \\
\text { de-out } \\
\text { ide-out } \\
\text { outside } \\
\text {-out }\end{array}$ & $\begin{array}{l}\text { observing sub- } \\
\text { in symmetrical } 100 \text { - } \\
\text { as follows (listed as: } \\
\text { ion) } \\
\text { out } \\
\text { hed }\end{array}$ \\
\hline
\end{tabular}


Table 2

\begin{tabular}{|c|c|c|c|c|}
\hline \multicolumn{5}{|c|}{ Subunit-specific Pharmacological Agents at Recombinant GlyRs } \\
\hline Agent & \begin{tabular}{|l|} 
Poten \\
cy $^{\#}$
\end{tabular} & Effect & Subunit specificity & References \\
\hline alkylbenzene sulfonate & ** & inhibition & $\alpha 2>\alpha 1$ & (Machu et al., 1998) \\
\hline atropine, & ** & inhibition & $\alpha 2>\alpha 1$ & (Maksay et al., 1999) \\
\hline bicuculline & * & inhibition & $\alpha 2 \beta>\alpha 2>\alpha 1 \beta>\alpha 1$ & $\begin{array}{l}\text { (Li and Slaughter, } \\
2007)\end{array}$ \\
\hline bilobalide & ** & inhibition & $\alpha 2>\alpha 1>\alpha 2 \beta>\alpha 1 \beta$ & $\begin{array}{c}\text { (Hawthorne et al., } \\
\text { 2006) }\end{array}$ \\
\hline $\begin{array}{l}n \text {-butyl- } \beta \text {-carboline-3- } \\
\text { carboxylate }\end{array}$ & ** & inhibition & $\alpha 2>\alpha 2 \beta$ & (Mangin et al., 2005) \\
\hline colchicine & ** & inhibition & $\alpha 2>\alpha 1$ & (Machu, 1998) \\
\hline cyanotriphenylborate & ** & inhibition & $\alpha 1>\alpha 2$ & $\begin{array}{c}\text { (Rundstrom et al., } \\
\text { 1994) }\end{array}$ \\
\hline dehydroepiandrosterone & ** & inhibition & $\alpha 1, \alpha 2>\alpha 1 \beta, \alpha 2 \beta, \alpha 4$ & (Maksay et al., 2001) \\
\hline $\begin{array}{l}\text { 5'7'-dichlorokynurenic } \\
\text { acid }\end{array}$ & * & inhibition & $\alpha 2>\alpha 1$ & (Han et al., 2004) \\
\hline $\begin{array}{l}\alpha \text {-ethyl } \alpha \text {-methyl- } \gamma- \\
\text { thiobutyrolactone }\end{array}$ & * & mixed & $\begin{array}{c}\text { potentiates } \alpha 1, \alpha 1 \beta, \alpha 3 \beta \\
\text { inhibits } \alpha 3\end{array}$ & (Steinbach et al., 2000) \\
\hline ginkgolide A & ** & inhibition & $\alpha 2 \beta>\alpha 1 \beta$ & $\begin{array}{c}\text { (Hawthorne et al., } \\
\text { 2006) }\end{array}$ \\
\hline ginkgolide B & $\star \star \star *$ & inhibition & $\alpha 1 \beta, \alpha 2 \beta>\alpha 1, \alpha 2$ & $\begin{array}{l}\text { (Kondratskaya et al., } \\
\text { 2005; Hawthorne et al., } \\
\text { 2006) }\end{array}$ \\
\hline ginkgolide C & ** & inhibition & $\alpha 1 \beta, \alpha 2 \beta>\alpha 1, \alpha 2$ & $\begin{array}{c}\text { (Hawthorne et al., } \\
2006)\end{array}$ \\
\hline ginkgolide $\mathrm{J}$ & ** & inhibition & $\alpha 1 \beta>\alpha 1$ & (Heads et al., 2008) \\
\hline NV-31 & 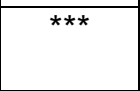 & potentiation & $\alpha 1>>\alpha 2, \alpha 3$ & $\begin{array}{l}\text { (Lynch and Chen, } \\
\text { 2008) }\end{array}$ \\
\hline picrotoxinin & ** & inhibition & $\begin{array}{c}\alpha 2, \alpha 3>\alpha 1>>\alpha 1 \beta, \alpha 1 \beta \\
\alpha 3 \beta\end{array}$ & $\begin{array}{l}\text { (Pribilla et al., 1992) } \\
\text { (Yang et al., 2007) }\end{array}$ \\
\hline pregnenolone & ** & potentiation & $\alpha 1 \gg \alpha 2, \alpha 1 \beta$ & (Maksay et al., 2001) \\
\hline progesterone & ** & inhibition & $\alpha 2>\alpha 1, \alpha 1 \beta$ & (Maksay et al., 2001) \\
\hline SR95531 & * & inhibition & $\alpha 2 \beta>\alpha 2, \alpha 1 \beta>\alpha 1$ & $\begin{array}{c}\text { (Li and Slaughter, } \\
\text { 2007) }\end{array}$ \\
\hline tropisetron & $\star \star * *$ & potentiation & $\alpha 1 \beta, \alpha 2 \beta>\alpha 1>>\alpha 2$ & $\begin{array}{c}\text { (Supplisson and } \\
\text { Chesnoy-Marchais, } \\
\text { 2000) }\end{array}$ \\
\hline zinc &  & potentiation & $\alpha 1, \alpha 1 \beta>\alpha 2, \alpha 2 \beta$ & (Miller et al., 2005b) \\
\hline zinc & ** & inhibition & $\alpha 1, \alpha 2>>\alpha 1 \beta, \alpha 2 \beta$ & (Miller et al., 2005a) \\
\hline $\begin{array}{l}\text { A single '>' sign in } \\
\text { denotes either a pot } \\
\text { \#Potency ranking ac }\end{array}$ & ding $t$ & $\begin{array}{r}\text { a potency d } \\
\text { nce of great } \\
\text { to the ab } \\
\text { alf-maximal }\end{array}$ & $\begin{array}{l}\text { rence is statistically signi } \\
\text { han an order of magnitud } \\
\text { nce of an effect. } \\
\text { fective concentration (M) } \\
>10^{-4}\end{array}$ & $\begin{array}{l}\text { t. A double '>>' sign } \\
\text { the presence relative } \\
<10^{-8},{ }^{\star \star} 10^{-6}-10^{-4},{ }^{*}\end{array}$ \\
\hline
\end{tabular}


Table 3.

\begin{tabular}{|c|c|c|c|c|c|}
\hline \multicolumn{6}{|c|}{ Biological effects of reducing GlyR gene expression or function } \\
\hline $\begin{array}{l}\text { Species } \\
\text { and } \\
\text { disorder }\end{array}$ & $\begin{array}{l}\text { Mutation and } \\
\text { subunit }\end{array}$ & $\begin{array}{l}\text { Mechanism } \\
\text { of } \\
\text { knockdown }\end{array}$ & $\begin{array}{l}\text { Effect on GlyR } \\
\text { function }\end{array}$ & Phenotype & $\begin{array}{l}\text { Referenc } \\
\text { es }\end{array}$ \\
\hline $\begin{array}{l}\text { Human, } \\
\text { hereditary } \\
\text { hyperekplexia }\end{array}$ & $\begin{array}{l}\alpha 1, \sim 20 \\
\text { different } \\
\text { mutations in } 70 \\
\text { different } \\
\text { pedigrees }\end{array}$ & $\begin{array}{l}\text { Usually } \\
\text { naturally } \\
\text { occurring single } \\
\text { nucleotide } \\
\text { polymorphisms, } \\
\text { leading to } \\
\text { dominant } \\
\text { negative } \\
\text { disruption of } \\
\text { receptor } \\
\text { function or } \\
\text { premature stop } \\
\text { codon }\end{array}$ & $\begin{array}{l}\text { reduced } \\
\text { magnitude of } \alpha 1 \\
\text { GlyR-mediated } \\
\text { currents, via } \\
\text { reduced } \\
\text { membrane } \\
\text { expression, open } \\
\text { probability, glycine } \\
\text { sensitivity or } \\
\text { unitary } \\
\text { conductance, with } \\
\text { some completely } \\
\text { eliminating } \alpha 1 \\
\text { GlyR expression } \\
\text { or function. }\end{array}$ & $\begin{array}{l}\text { Exaggerated startle } \\
\text { reflex to unexpected } \\
\text { stimuli, often } \\
\text { accompanied by } \\
\text { temporary but complete } \\
\text { muscular rigidity. Severe } \\
\text { muscular rigidity } \\
\text { (hypertonia) in } \\
\text { neonates. Successfully } \\
\text { treated with } \\
\text { clonazepam. }\end{array}$ & $\begin{array}{l}\text { (Bakker et } \\
\text { al., 2006) }\end{array}$ \\
\hline $\begin{array}{l}\text { Human, } \\
\text { hereditary } \\
\text { hyperekplexia }\end{array}$ & $\begin{array}{l}\beta, \text { G229D/loss } \\
\text { of exon } 5\end{array}$ & $\begin{array}{l}\text { Naturally } \\
\text { occurring } \\
\text { mutations, } \\
\text { compound } \\
\text { heterozygous } \\
\text { effect }\end{array}$ & $\begin{array}{l}\text { Decreased glycine } \\
\text { sensitivity }\end{array}$ & As above & $\begin{array}{l}\text { (Rees et } \\
\text { al., 2002) }\end{array}$ \\
\hline $\begin{array}{l}\text { Mouse, } \\
\text { Spasmodic }\end{array}$ & $\alpha 1$, A52S & $\begin{array}{l}\text { Naturally } \\
\text { occurring, } \\
\text { autosomal } \\
\text { recessive }\end{array}$ & $\begin{array}{l}\text { Decreased glycine } \\
\text { sensitivity }\end{array}$ & $\begin{array}{l}\text { As for human } \\
\text { hyperekplexia }\end{array}$ & $\begin{array}{l}\text { (Ryan et } \\
\text { al., 1994; } \\
\text { Saul et al., } \\
\text { 1994) }\end{array}$ \\
\hline $\begin{array}{l}\text { Mouse, } \\
\text { Oscillator }\end{array}$ & $\begin{array}{l}\alpha 1,7-b p \\
\text { deletion } \\
\text { leading to } \\
\text { frameshift and } \\
\text { premature stop } \\
\text { codon }\end{array}$ & $\begin{array}{l}\text { Naturally } \\
\text { occurring, } \\
\text { autosomal } \\
\text { recessive }\end{array}$ & $\begin{array}{l}\text { Reduced receptor } \\
\text { expression }\end{array}$ & $\begin{array}{l}\text { Mice appear normal until } \\
\text { the } 2^{\text {nd }} \text { postnatal week } \\
\text { whereupon they develop } \\
\text { progressively worsening } \\
\text { muscular rigidity and } \\
\text { tremor, spastic gait, } \\
\text { exaggerated startle } \\
\text { responses and die } \\
\text { within } 10 \text { days. }\end{array}$ & $\begin{array}{l}\text { (Buckwalter } \\
\text { et al., 1994; } \\
\text { Kling et al., } \\
1997)\end{array}$ \\
\hline $\begin{array}{l}\text { Mouse, } \\
\text { Cincinatti }\end{array}$ & $\begin{array}{l}\alpha 1 \text {, duplication } \\
\text { of exon } 5 \text {, } \\
\text { resulting in a } \\
\text { frameshift } \\
\text { and } \\
\text { premature } \\
\text { protein } \\
\text { truncation. }\end{array}$ & $\begin{array}{l}\text { Naturally } \\
\text { occurring splice } \\
\text { variant, } \\
\text { autosomal } \\
\text { recessive }\end{array}$ & $\begin{array}{l}\text { Reduced receptor } \\
\text { expression }\end{array}$ & $\begin{array}{l}\text { As for human } \\
\text { hyperekplexia }\end{array}$ & $\begin{array}{l}\text { (Holland et } \\
\text { al., 2006) }\end{array}$ \\
\hline $\begin{array}{l}\text { Cow, } \\
\text { Myoclonus }\end{array}$ & $\begin{array}{l}\alpha 1, \text { nonsense } \\
\text { mutation } \\
\text { (Y24X) leading } \\
\text { to a premature } \\
\text { stop codon }\end{array}$ & $\begin{array}{l}\text { Naturally } \\
\text { occurring, } \\
\text { autosomal } \\
\text { recessive }\end{array}$ & $\begin{array}{l}\text { Reduced receptor } \\
\text { expression }\end{array}$ & $\begin{array}{l}\text { As for human } \\
\text { hyperekplexia }\end{array}$ & $\begin{array}{l}\text { (Pierce et } \\
\text { al., 2001) }\end{array}$ \\
\hline Mouse & $\alpha 2$ knockout & $\begin{array}{l}\text { gene targeting } \\
\text { in embryonic } \\
\text { stem cells }\end{array}$ & $\begin{array}{l}\text { Reduced receptor } \\
\text { expression }\end{array}$ & $\begin{array}{l}\text { No overt behavioural } \\
\text { phenotype or } \\
\text { neuroanatomical } \\
\text { changes. Cortical } \\
\text { neurons were no longer }\end{array}$ & $\begin{array}{l}\text { (Young- } \\
\text { Pearse et } \\
\text { al., 2006) }\end{array}$ \\
\hline
\end{tabular}




\begin{tabular}{|c|c|c|c|c|c|}
\hline & & & & $\begin{array}{l}\text { responsive to applied } \\
\text { glycine. }\end{array}$ & \\
\hline Mouse & $\alpha 2$ knockdown & siRNA & $\begin{array}{l}\text { Reduced receptor } \\
\text { expression }\end{array}$ & $\begin{array}{l}\text { Decreased number of } \\
\text { photoreceptors while } \\
\text { increasing the number } \\
\text { of other retinal cell } \\
\text { types. (Enhanced } \alpha 2 \\
\text { expression increased } \\
\text { rod photoreceptor } \\
\text { numbers.) }\end{array}$ & $\begin{array}{l}\text { (Young and } \\
\text { Cepko, } \\
\text { 2004) }\end{array}$ \\
\hline Zebrafish & $\alpha 2$ knockdown & siRNA & $\begin{array}{l}\text { Reduced receptor } \\
\text { expression }\end{array}$ & $\begin{array}{l}\text { No overt behavioural } \\
\text { phenotype, although a } \\
\text { decrease in the number } \\
\text { of spinal interneurons } \\
\text { was observed }\end{array}$ & $\begin{array}{l}\text { (McDearmi } \\
\text { d et al., } \\
\text { 2006) }\end{array}$ \\
\hline Mouse & $\alpha 3$ knockout & $\begin{array}{l}\text { gene targeting } \\
\text { in embryonic } \\
\text { stem cells }\end{array}$ & $\begin{array}{l}\text { Reduced } \\
\text { receptor } \\
\text { expression }\end{array}$ & $\begin{array}{l}\text { No overt behavioural } \\
\text { phenotype. Normal } \\
\text { responses to tactile and } \\
\text { acute inflammatory pain } \\
\text { stimuli. Reduction in } \\
\text { chronic pain } \\
\text { sensitisation induced by } \\
\text { spinal } P G E_{2} \text { injection or } \\
\text { peripheral inflammation. }\end{array}$ & $\begin{array}{l}\text { (Harvey et } \\
\text { al., 2004) }\end{array}$ \\
\hline $\begin{array}{l}\text { Mouse, } \\
\text { Spastic }\end{array}$ & $\begin{array}{l}\beta, 7.1 \mathrm{~kb} \text { line- } \\
1 \text { insert }\end{array}$ & $\begin{array}{l}\text { Naturally } \\
\text { occurring splice } \\
\text { variant, } \\
\text { autosomal } \\
\text { recessive }\end{array}$ & $\begin{array}{l}\text { Reduced receptor } \\
\text { expression via } \\
\text { aberrant splicing }\end{array}$ & $\begin{array}{l}\text { As for human } \\
\text { hyperekplexia }\end{array}$ & $\begin{array}{l}\text { (Kingsmore } \\
\text { et al., 1994; } \\
\text { Mulhardt et } \\
\text { al., 1994; } \\
\text { Hartenstein } \\
\text { et al., 1996) }\end{array}$ \\
\hline $\begin{array}{l}\text { Zebrafish, } \\
\text { Bandoneon }\end{array}$ & $\begin{array}{l}\beta, \text { missense or } \\
\text { nonsense } \\
\text { mutations } \\
\text { D78X, L255R } \\
\text { or R275H }\end{array}$ & $\begin{array}{l}\text { Naturally } \\
\text { occurring }\end{array}$ & $\begin{array}{l}\text { Reduced GlyR } \\
\text { clustering }\end{array}$ & $\begin{array}{l}\text { Aberrant trunk muscle } \\
\text { contractions in response } \\
\text { to tactile stimuli }\end{array}$ & $\begin{array}{l}\text { (Hirata et } \\
\text { al., 2005) }\end{array}$ \\
\hline
\end{tabular}




\section{References}

Ahmadi, S., Lippross, S., Neuhuber, W. L., Zeilhofer, H. U., 2002. PGE(2) selectively blocks inhibitory glycinergic neurotransmission onto rat superficial dorsal horn neurons. Nat Neurosci. 5, 34-40.

Ali, D. W., Drapeau, P., Legendre, P., 2000. Development of spontaneous glycinergic currents in the Mauthner neuron of the zebrafish embryo. J Neurophysiol. 84, 17261736.

Aprison, M. H., Werman, R., 1965. The distribution of glycine in cat spinal cord and roots. Life Sci. 4, 2075-2083.

Araki, T., Yamano, M., Murakami, T., Wanaka, A., Betz, H., Tohyama, M., 1988. Localization of glycine receptors in the rat central nervous system: an immunocytochemical analysis using monoclonal antibody. Neuroscience. 25, 613624.

Bakker, M. J., van Dijk, J. G., van den Maagdenberg, A. M., Tijssen, M. A., 2006. Startle syndromes. Lancet Neurol. 5, 513-524.

Barker, J. L., Ransom, B. R., 1978. Amino acid pharmacology of mammalian central neurones grown in tissue culture. J Physiol. 280, 331-354.

Beato, M., Groot-Kormelink, P. J., Colquhoun, D., Sivilotti, L. G., 2002. Openings of the rat recombinant alpha 1 homomeric glycine receptor as a function of the number of agonist molecules bound. J Gen Physiol. 119, 443-466.

Beato, M., Groot-Kormelink, P. J., Colquhoun, D., Sivilotti, L. G., 2004. The activation mechanism of alpha1 homomeric glycine receptors. J Neurosci. 24, 895-906.

Beato, M., Sivilotti, L. G., 2007. Single-channel properties of glycine receptors of juvenile rat spinal motoneurones in vitro. J Physiol. 580, 497-506.

Becker, C. M., Hoch, W., Betz, H., 1988. Glycine receptor heterogeneity in rat spinal cord during postnatal development. Embo J. 7, 3717-3726.

Bedet, C., Bruusgaard, J. C., Vergo, S., Groth-Pedersen, L., Eimer, S., Triller, A., Vannier, C., 2006. Regulation of gephyrin assembly and glycine receptor synaptic stability. J Biol Chem. 281, 30046-30056.

Bormann, J., Rundstrom, N., Betz, H., Langosch, D., 1993. Residues within transmembrane segment M2 determine chloride conductance of glycine receptor homo- and hetero-oligomers. Embo J. 12, 3729-3737.

Brejc, K., van Dijk, W. J., Smit, A. B., Sixma, T. K., 2002. The 2.7 A structure of AChBP, homologue of the ligand-binding domain of the nicotinic acetylcholine receptor. Novartis Found Symp. 245, 22-29; discussion 29-32, 165-168.

Buckwalter, M. S., Cook, S. A., Davisson, M. T., White, W. F., Camper, S. A., 1994. A frameshift mutation in the mouse alpha 1 glycine receptor gene (Glra1) results in progressive neurological symptoms and juvenile death. Hum Mol Genet. 3, 20252030.

Burzomato, V., Beato, M., Groot-Kormelink, P. J., Colquhoun, D., Sivilotti, L. G., 2004. Single-channel behavior of heteromeric alphalbeta glycine receptors: an attempt to detect a conformational change before the channel opens. J Neurosci. 24, 1092410940.

Burzomato, V., Groot-Kormelink, P. J., Sivilotti, L. G., Beato, M., 2003. Stoichiometry of recombinant heteromeric glycine receptors revealed by a pore-lining region point mutation. Receptors Channels. 9, 353-361. 
Corringer, P. J., Le Novere, N., Changeux, J. P., 2000. Nicotinic receptors at the amino acid level. Annu Rev Pharmacol Toxicol. 40, 431-458.

Curtis, D. R., Hosli, L., Johnston, G. A., 1967. Inhibition of spinal neurons by glycine. Nature. 215, 1502-1503.

Davidoff, R. A., Shank, R. P., Graham, L. T., Jr., Aprison, M. H., Werman, R., 1967. Association of glycine with spinal interneurones. Nature. 214, 680-681.

Deleuze, C., Runquist, M., Orcel, H., Rabie, A., Dayanithi, G., Alonso, G., Hussy, N., 2005. Structural difference between heteromeric somatic and homomeric axonal glycine receptors in the hypothalamo-neurohypophysial system. Neuroscience. 135, 475-483.

Flint, A. C., Liu, X., Kriegstein, A. R., 1998. Nonsynaptic glycine receptor activation during early neocortical development. Neuron. 20, 43-53.

Fritschy, J. M., Harvey, R. J., Schwarz, G., 2008. Gephyrin: where do we stand, where do we go? Trends Neurosci. 31, 257-264.

Greferath, U., Brandstatter, J. H., Wassle, H., Kirsch, J., Kuhse, J., Grunert, U., 1994. Differential expression of glycine receptor subunits in the retina of the rat: a study using immunohistochemistry and in situ hybridization. Vis Neurosci. 11, 721-729.

Grenningloh, G., Rienitz, A., Schmitt, B., Methfessel, C., Zensen, M., Beyreuther, K., Gundelfinger, E. D., Betz, H., 1987. The strychnine-binding subunit of the glycine receptor shows homology with nicotinic acetylcholine receptors. Nature. 328, 215 220.

Grenningloh, G., Schmieden, V., Schofield, P. R., Seeburg, P. H., Siddique, T., Mohandas, T. K., Becker, C. M., Betz, H., 1990. Alpha subunit variants of the human glycine receptor: primary structures, functional expression and chromosomal localization of the corresponding genes. Embo J. 9, 771-776.

Griffon, N., Buttner, C., Nicke, A., Kuhse, J., Schmalzing, G., Betz, H., 1999. Molecular determinants of glycine receptor subunit assembly. Embo J. 18, 4711-4721.

Grudzinska, J., Schemm, R., Haeger, S., Nicke, A., Schmalzing, G., Betz, H., Laube, B., 2005. The beta subunit determines the ligand binding properties of synaptic glycine receptors. Neuron. 45, 727-739.

Han, Y., Li, P., Slaughter, M. M., 2004. Selective antagonism of rat inhibitory glycine receptor subunits. J Physiol. 554, 649-658.

Hartenstein, B., Schenkel, J., Kuhse, J., Besenbeck, B., Kling, C., Becker, C. M., Betz, H., Weiher, H., 1996. Low level expression of glycine receptor beta subunit transgene is sufficient for phenotype correction in spastic mice. Embo J. 15, 12751282.

Harvey, R. J., Depner, U. B., Wassle, H., Ahmadi, S., Heindl, C., Reinold, H., Smart, T. G., Harvey, K., Schutz, B., Abo-Salem, O. M., Zimmer, A., Poisbeau, P., Welzl, H., Wolfer, D. P., Betz, H., Zeilhofer, H. U., Muller, U., 2004. GlyR alpha3: an essential target for spinal PGE2-mediated inflammatory pain sensitization. Science. 304, 884887.

Harvey, R. J., Schmieden, V., Von Holst, A., Laube, B., Rohrer, H., Betz, H., 2000. Glycine receptors containing the alpha4 subunit in the embryonic sympathetic nervous system, spinal cord and male genital ridge. Eur J Neurosci. 12, 994-1001.

Haverkamp, S., Muller, U., Harvey, K., Harvey, R. J., Betz, H., Wassle, H., 2003. Diversity of glycine receptors in the mouse retina: localization of the alpha3 subunit. J Comp Neurol. 465, 524-539.

Haverkamp, S., Muller, U., Zeilhofer, H. U., Harvey, R. J., Wassle, H., 2004. Diversity of glycine receptors in the mouse retina: localization of the alpha2 subunit. J Comp Neurol. 477, 399-411. 
Hawthorne, R., Cromer, B. A., Ng, H. L., Parker, M. W., Lynch, J. W., 2006. Molecular determinants of ginkgolide binding in the glycine receptor pore. J Neurochem. 98, 395-407.

Heads, J. A., Hawthorne, R. L., Lynagh, T., Lynch, J. W., 2008. Structure-Activity Analysis of Ginkgolide Binding in the Glycine Receptor Pore. J Neurochem.

Heinze, L., Harvey, R. J., Haverkamp, S., Wassle, H., 2007. Diversity of glycine receptors in the mouse retina: localization of the alpha4 subunit. J Comp Neurol. 500, 693-707.

Hilf, R. J., Dutzler, R., 2008. X-ray structure of a prokaryotic pentameric ligand-gated ion channel. Nature. 452, 375-379.

Hirata, H., Saint-Amant, L., Downes, G. B., Cui, W. W., Zhou, W., Granato, M., Kuwada, J. Y., 2005. Zebrafish bandoneon mutants display behavioral defects due to a mutation in the glycine receptor beta-subunit. Proc Natl Acad Sci U S A. 102, 8345-8350.

Holland, K. D., Fleming, M. T., Cheek, S., Moran, J. L., Beier, D. R., Meisler, M. H., 2006. De novo exon duplication in a new allele of mouse Glra1 (spasmodic). Genetics. 174, 2245-2247.

Jeong, H. J., Jang, I. S., Moorhouse, A. J., Akaike, N., 2003. Activation of presynaptic glycine receptors facilitates glycine release from presynaptic terminals synapsing onto rat spinal sacral dorsal commissural nucleus neurons. J Physiol. 550, 373-383.

Kim, E. Y., Schrader, N., Smolinsky, B., Bedet, C., Vannier, C., Schwarz, G., Schindelin, H., 2006. Deciphering the structural framework of glycine receptor anchoring by gephyrin. Embo J. 25, 1385-1395.

Kingsmore, S. F., Suh, D., Seldin, M. F., 1994. Genetic mapping of the glycine receptor alpha 3 subunit on mouse chromosome 8. Mamm Genome. 5, 831-832.

Kling, C., Koch, M., Saul, B., Becker, C. M., 1997. The frameshift mutation oscillator (Glra1(spd-ot)) produces a complete loss of glycine receptor alpha1-polypeptide in mouse central nervous system. Neuroscience. 78, 411-417.

Kneussel, M., Betz, H., 2000. Receptors, gephyrin and gephyrin-associated proteins: novel insights into the assembly of inhibitory postsynaptic membrane specializations. J Physiol. 525 Pt 1, 1-9.

Kondratskaya, E. L., Betz, H., Krishtal, O. A., Laube, B., 2005. The beta subunit increases the ginkgolide B sensitivity of inhibitory glycine receptors. Neuropharmacology. 49, 945-951.

Kuhse, J., Laube, B., Magalei, D., Betz, H., 1993. Assembly of the inhibitory glycine receptor: identification of amino acid sequence motifs governing subunit stoichiometry. Neuron. 11, 1049-1056.

Kungel, M., Friauf, E., 1997. Physiology and pharmacology of native glycine receptors in developing rat auditory brainstem neurons. Brain Res Dev Brain Res. 102, 157-165.

Langosch, D., Thomas, L., Betz, H., 1988. Conserved quaternary structure of ligandgated ion channels: the postsynaptic glycine receptor is a pentamer. Proc Natl Acad Sci U S A. 85, 7394-7398.

Legendre, P., 2001. The glycinergic inhibitory synapse. Cell Mol Life Sci. 58, 760-793.

Lewis, T. M., Schofield, P. R., McClellan, A. M., 2003. Kinetic determinants of agonist action at the recombinant human glycine receptor. J Physiol. 549, 361-374.

Li, P., Slaughter, M., 2007. Glycine receptor subunit composition alters the action of GABA antagonists. Vis Neurosci. 24, 513-521.

Lynch, J. W., 2004. Molecular structure and function of the glycine receptor chloride channel. Physiol Rev. 84, 1051-1095. 
Lynch, J. W., Chen, X., 2008. Subunit-specific potentiation of recombinant glycine receptors by NV-31, a bilobalide-derived compound. Neurosci Lett. 435, 147-151.

Lynch, J. W., Rajendra, S., Pierce, K. D., Handford, C. A., Barry, P. H., Schofield, P. R., 1997. Identification of intracellular and extracellular domains mediating signal transduction in the inhibitory glycine receptor chloride channel. Embo J. 16, 110120.

Machu, T. K., 1998. Colchicine competitively antagonizes glycine receptors expressed in Xenopus oocytes. Neuropharmacology. 37, 391-396.

Machu, T. K., Mihic, S. J., Dildy-Mayfield, J. E., 1998. Selective actions of a detergent on ligand-gated ion channels expressed in Xenopus oocytes. J Pharmacol Exp Ther. 284, 32-36.

Maksay, G., Laube, B., Betz, H., 1999. Selective blocking effects of tropisetron and atropine on recombinant glycine receptors. J Neurochem. 73, 802-806.

Maksay, G., Laube, B., Betz, H., 2001. Subunit-specific modulation of glycine receptors by neurosteroids. Neuropharmacology. 41, 369-376.

Malosio, M. L., Grenningloh, G., Kuhse, J., Schmieden, V., Schmitt, B., Prior, P., Betz, H., 1991a. Alternative splicing generates two variants of the alpha 1 subunit of the inhibitory glycine receptor. J Biol Chem. 266, 2048-2053.

Malosio, M. L., Marqueze-Pouey, B., Kuhse, J., Betz, H., 1991b. Widespread expression of glycine receptor subunit mRNAs in the adult and developing rat brain. Embo J. 10, 2401-2409.

Mangin, J. M., Baloul, M., Prado De Carvalho, L., Rogister, B., Rigo, J. M., Legendre, P., 2003. Kinetic properties of the alpha 2 homo-oligomeric glycine receptor impairs a proper synaptic functioning. J Physiol. 553, 369-386.

Mangin, J. M., Guyon, A., Eugene, D., Paupardin-Tritsch, D., Legendre, P., 2002. Functional glycine receptor maturation in the absence of glycinergic input in dopaminergic neurones of the rat substantia nigra. J Physiol. 542, 685-697.

Mangin, J. M., Nguyen, L., Gougnard, C., Hans, G., Rogister, B., Belachew, S., Moonen, G., Legendre, P., Rigo, J. M., 2005. Developmental regulation of beta-carbolineinduced inhibition of glycine-evoked responses depends on glycine receptor beta subunit expression. Mol Pharmacol. 67, 1783-1796.

McDearmid, J. R., Liao, M., Drapeau, P., 2006. Glycine receptors regulate interneuron differentiation during spinal network development. Proc Natl Acad Sci U S A. 103, 9679-9684.

Meier, J. C., Henneberger, C., Melnick, I., Racca, C., Harvey, R. J., Heinemann, U., Schmieden, V., Grantyn, R., 2005. RNA editing produces glycine receptor alpha3(P185L), resulting in high agonist potency. Nat Neurosci. 8, 736-744.

Meyer, G., Kirsch, J., Betz, H., Langosch, D., 1995. Identification of a gephyrin binding motif on the glycine receptor beta subunit. Neuron. 15, 563-572.

Miller, P. S., Beato, M., Harvey, R. J., Smart, T. G., 2005a. Molecular determinants of glycine receptor alphabeta subunit sensitivities to $\mathrm{Zn} 2+$-mediated inhibition. $\mathrm{J}$ Physiol. 566, 657-670.

Miller, P. S., Da Silva, H. M., Smart, T. G., 2005b. Molecular basis for zinc potentiation at strychnine-sensitive glycine receptors. J Biol Chem. 280, 37877-37884.

Miyazawa, A., Fujiyoshi, Y., Unwin, N., 2003. Structure and gating mechanism of the acetylcholine receptor pore. Nature. 423, 949-955.

Mulhardt, C., Fischer, M., Gass, P., Simon-Chazottes, D., Guenet, J. L., Kuhse, J., Betz, H., Becker, C. M., 1994. The spastic mouse: aberrant splicing of glycine receptor beta subunit mRNA caused by intronic insertion of L1 element. Neuron. 13, 10031015 . 
Oertel, J., Villmann, C., Kettenmann, H., Kirchhoff, F., Becker, C. M., 2007. A novel glycine receptor beta subunit splice variant predicts an unorthodox transmembrane topology. Assembly into heteromeric receptor complexes. J Biol Chem. 282, 27982807.

Okabe, A., Kilb, W., Shimizu-Okabe, C., Hanganu, I. L., Fukuda, A., Luhmann, H. J., 2004. Homogenous glycine receptor expression in cortical plate neurons and CajalRetzius cells of neonatal rat cerebral cortex. Neuroscience. 123, 715-724.

Pfeiffer, F., Graham, D., Betz, H., 1982. Purification by affinity chromatography of the glycine receptor of rat spinal cord. J Biol Chem. 257, 9389-9393.

Piechotta, K., Weth, F., Harvey, R. J., Friauf, E., 2001. Localization of rat glycine receptor alpha1 and alpha2 subunit transcripts in the developing auditory brainstem. J Comp Neurol. 438, 336-352.

Pierce, K. D., Handford, C. A., Morris, R., Vafa, B., Dennis, J. A., Healy, P. J., Schofield, P. R., 2001. A nonsense mutation in the alpha1 subunit of the inhibitory glycine receptor associated with bovine myoclonus. Mol Cell Neurosci. 17, 354-363.

Pribilla, I., Takagi, T., Langosch, D., Bormann, J., Betz, H., 1992. The atypical M2 segment of the beta subunit confers picrotoxinin resistance to inhibitory glycine receptor channels. Embo J. 11, 4305-4311.

Rajendra, S., Lynch, J. W., Pierce, K. D., French, C. R., Barry, P. H., Schofield, P. R., 1995. Mutation of an arginine residue in the human glycine receptor transforms betaalanine and taurine from agonists into competitive antagonists. Neuron. 14, 169-175.

Rees, M. I., Lewis, T. M., Kwok, J. B., Mortier, G. R., Govaert, P., Snell, R. G., Schofield, P. R., Owen, M. J., 2002. Hyperekplexia associated with compound heterozygote mutations in the beta-subunit of the human inhibitory glycine receptor (GLRB). Hum Mol Genet. 11, 853-860.

Rivera, C., Voipio, J., Payne, J. A., Ruusuvuori, E., Lahtinen, H., Lamsa, K., Pirvola, U., Saarma, M., Kaila, K., 1999. The K+/Cl- co-transporter KCC2 renders GABA hyperpolarizing during neuronal maturation. Nature. 397, 251-255.

Rundstrom, N., Schmieden, V., Betz, H., Bormann, J., Langosch, D., 1994. Cyanotriphenylborate: subtype-specific blocker of glycine receptor chloride channels. Proc Natl Acad Sci U S A. 91, 8950-8954.

Ryan, S. G., Buckwalter, M. S., Lynch, J. W., Handford, C. A., Segura, L., Shiang, R., Wasmuth, J. J., Camper, S. A., Schofield, P., O'Connell, P., 1994. A missense mutation in the gene encoding the alpha 1 subunit of the inhibitory glycine receptor in the spasmodic mouse. Nat Genet. 7, 131-135.

Sato, K., Zhang, J. H., Saika, T., Sato, M., Tada, K., Tohyama, M., 1991. Localization of glycine receptor alpha 1 subunit mRNA-containing neurons in the rat brain: an analysis using in situ hybridization histochemistry. Neuroscience. 43, 381-395.

Saul, B., Schmieden, V., Kling, C., Mulhardt, C., Gass, P., Kuhse, J., Becker, C. M., 1994. Point mutation of glycine receptor alpha 1 subunit in the spasmodic mouse affects agonist responses. FEBS Lett. 350, 71-76.

Schmieden, V., Grenningloh, G., Schofield, P. R., Betz, H., 1989. Functional expression in Xenopus oocytes of the strychnine binding $48 \mathrm{kd}$ subunit of the glycine receptor. Embo J. 8, 695-700.

Shan, Q., Haddrill, J. L., Lynch, J. W., 2001. Ivermectin, an unconventional agonist of the glycine receptor chloride channel. J Biol Chem. 276, 12556-12564.

Simon, J., Wakimoto, H., Fujita, N., Lalande, M., Barnard, E. A., 2004. Analysis of the set of GABA(A) receptor genes in the human genome. J Biol Chem. 279, 4142241435. 
Singer, J. H., Talley, E. M., Bayliss, D. A., Berger, A. J., 1998. Development of glycinergic synaptic transmission to rat brain stem motoneurons. J Neurophysiol. 80, 2608-2620.

Steinbach, J. H., Bracamontes, J., Yu, L., Zhang, P., Covey, D. F., 2000. Subunit-specific action of an anticonvulsant thiobutyrolactone on recombinant glycine receptors involves a residue in the M2 membrane-spanning region. Mol Pharmacol. 58, 11-17.

Supplisson, S., Chesnoy-Marchais, D., 2000. Glycine receptor beta subunits play a critical role in potentiation of glycine responses by ICS-205,930. Mol Pharmacol. 58, 763-770.

Takahashi, T., Momiyama, A., Hirai, K., Hishinuma, F., Akagi, H., 1992. Functional correlation of fetal and adult forms of glycine receptors with developmental changes in inhibitory synaptic receptor channels. Neuron. 9, 1155-1161.

Turecek, R., Trussell, L. O., 2001. Presynaptic glycine receptors enhance transmitter release at a mammalian central synapse. Nature. 411, 587-590.

Turecek, R., Trussell, L. O., 2002. Reciprocal developmental regulation of presynaptic ionotropic receptors. Proc Natl Acad Sci U S A. 99, 13884-13889.

van den Pol, A. N., Gorcs, T., 1988. Glycine and glycine receptor immunoreactivity in brain and spinal cord. J Neurosci. 8, 472-492.

Veruki, M. L., Gill, S. B., Hartveit, E., 2007. Spontaneous IPSCs and glycine receptors with slow kinetics in wide-field amacrine cells in the mature rat retina. J Physiol. 581, 203-219.

Wang, F., Xiao, C., Ye, J. H., 2005. Taurine activates excitatory non-synaptic glycine receptors on dopamine neurones in ventral tegmental area of young rats. J Physiol. 565, 503-516.

Watanabe, E., Akagi, H., 1995. Distribution patterns of mRNAs encoding glycine receptor channels in the developing rat spinal cord. Neurosci Res. 23, 377-382.

Webb, T. I., Lynch, J. W., 2007. Molecular pharmacology of the glycine receptor chloride channel. Curr Pharm Des. 13, 2350-2367.

Werman, R., Davidoff, R. A., Aprison, M. H., 1967. Inhibition of motoneurones by iontophoresis of glycine. Nature. 214, 681-683.

Yang, Z., Cromer, B. A., Harvey, R. J., Parker, M. W., Lynch, J. W., 2007. A proposed structural basis for picrotoxinin and picrotin binding in the glycine receptor pore. $\mathrm{J}$ Neurochem. 103, 580-589.

Ye, J. H., Wang, F., Krnjevic, K., Wang, W., Xiong, Z. G., Zhang, J., 2004. Presynaptic glycine receptors on GABAergic terminals facilitate discharge of dopaminergic neurons in ventral tegmental area. J Neurosci. 24, 8961-8974.

Young, T. L., Cepko, C. L., 2004. A role for ligand-gated ion channels in rod photoreceptor development. Neuron. 41, 867-879.

Young-Pearse, T. L., Ivic, L., Kriegstein, A. R., Cepko, C. L., 2006. Characterization of mice with targeted deletion of glycine receptor alpha 2. Mol Cell Biol. 26, 57285734.

Zarbin, M. A., Wamsley, J. K., Kuhar, M. J., 1981. Glycine receptor: light microscopic autoradiographic localization with $[3 \mathrm{H}]$ strychnine. J Neurosci. 1, 532-547. 